\title{
INNOVATIVE TEXTILES INDUSTRY AND ITS FUTURE WITHIN THE CONCEPT OF CIRCULAR ECONOMY - FROM THE GLOBAL TO REGIONAL PERSPECTIVE
}

\author{
ZOFIA WYSOKIŃSKA
}

\begin{abstract}
The paper deals with the complex analyses of production, export and import of products in the textile industry in different countries of the world. The largest manufacturers and exporters of textile products are identified. Trends in production capacity changes in the industry over the past years are analysed. The place and role of textile industry development in the context of the implementation of the circular economy principle in line with the EU priorities are substantiated. The main directions of perspective development of the textile industry are identified. Two main national documents that have been developed in Poland which set out the current development directions of the country in the field of sustainable development and environmental protection: Strategy for Responsible Development until the year 2020 (with the perspective until the year 2030) and National Waste Management Plan elaborated in the year 2014. The article provides a detailed analysis of the development of regional industry, including the textile industry based on the city of Lodz (Poland). The identified areas of smart specialisations of the Region of Lodz include the following sectors of economic activity: modern textile and fashion industry; advanced building materials; medicine, pharmacy, and cosmetic industry; power generation (including Renewable Energy Sources); innovative agriculture and agricultural and food processing; computer science and telecommunication. The paper proposes the main directions of the textile industry development in the example of Poland: 1 ) generation of minimal waste in the production process (1R - with application of the most innovative technology), 2) its maximum re-use (2R), 3) application of the third method within the three $R$ formula (reduce, reuse, recycle) which is recycling (3R), the awareness of the importance of which among producers and citizens in many countries is systematically growing.
\end{abstract}

Keywords: textile industry, Circular Economy, global economy, recycling, waste, production process.

\section{INTRODUCTION}

Textile industry belongs to the sectors that are systematically and steadily growing in the world $\operatorname{market}^{1}[1$, p. 18]. This applies to both textiles and knitted fabrics, for which demand in the global and

\footnotetext{
${ }^{1}$ Globally, the USD 1.3 trillion clothing industry employs more than 300 million people along the value chain; the production of cotton alone accounts for almost $7 \%$ of all employment in some low-income countries.
} 
European markets as well as in developing markets is growing steadily, not only with increasing population, but also with growing prosperity in many countries and good announcements concerning the development of the global economy and in majority of its regions. The following are the developmental trends of the situation in the markets of various countries and regions of the world, which clearly confirm these observations. There are also trends leading to the modernization of this sector and the increase of its innovativeness and orientation to pro-ecological textiles, which are aimed at reducing the scale of waste growth and/or re-using them.

\section{RESUlts}

\section{Cotton Fabrics SITC 652}

In 2015, the value (in current US\$) of exports of "cotton and woven fabrics (not including narrow or special fabrics)" (SITC group 652) decreased by 7.7 percent (compared to -3.1 percent average growth rate in the period 2011-2015) to reach 29.6 bn US $\$$, while imports decreased by 5.1 percent to reach 22.9 bn US\$. Exports of this commodity accounted for 1.4 percent of world exports of SITC section 6, and 0.2 percent of total world merchandise exports.

China, Pakistan and India were the top exporters in 2015. They accounted for 48.4, 7.8 and 6.0 percent of world exports, respectively. Bangladesh, Viet Nam and China were the top destinations, with 17.2, 7.5 and 5.4 percent of world imports, respectively.

The top 15 countries/areas accounted for 88.2 and 63.9 percent of total world exports and imports, respectively. In 2015, China was the country/area with the highest value of net exports (+13.1 bn US $\$$ ), followed by Pakistan (+2.3 bn US\$). By MDG (Most Developed Group ${ }^{2}$ ), the largest surpluses in this product group were recorded by Eastern Asia (+13.4 bn US\$), Developed Europe (+531.4 mil US\$) and Western Asia (+276.2 mil US\$). The largest trade deficits were recorded by South-eastern Asia (-2.7 bn US\$), Latin America and the Caribbean (-1.3 bn USS) and Northern Africa (-1.0 bn US\$) [2, p. 296].

\section{Fabrics woven of man-made textile materials (not narrow or special fabrics) - SITC 653}

In 2015, the value (in current US\$) of exports of "fabrics, woven fabrics, man-made textile materials (not narrow or special fabrics)" (SITC group 653) decreased by 5.9 percent (compared to 0.4 percent average growth rate in 20112015) to reach 44.6 bn US $\$$ while imports decreased by 4.6 percent to reach 35.2 bn US\$. Exports of this commodity accounted for 2.2 percent of world exports of SITC section 6, and 0.3 percent of total world merchandise exports. China, Rep. of Korea and India were the top exporters in 2015. They accounted for 48.1, 5.4 and 4.7 percent of world exports, respectively. Viet Nam, China and USA were the top destinations, with 10.8, 6.3 and 4.4 percent of world imports, respectively.

The top 15 countries/areas accounted for 89.2 and 53.4 percent of total world exports and imports, respectively. In 2015, China was the country/area with the highest value of net exports (+19.3 bn US\$), followed by Rep. of Korea (+2.0 bn US\$).

By MDG regions, the largest surpluses in this product group were recorded by Eastern Asia (+23.0 bn US\$), Developed Asia-Pacific (+805.1 min US\$) and Developed Europe (+356.9 min US\$). The largest trade deficits were recorded by South-eastern Asia ( -4.8 bn US\$), Latin America and the Caribbean (-3.2 bn US\$) and Northern Africa (-1.7 bn US\$) [2, p. 297].

\section{Other textile fabrics- woven SITC 654}

In 2015, the value (in current US\$) of exports of "other textile fabrics - woven" (SITC group 654) decreased by 9.8 percent (compared to -3.7 percent average growth rate in 20112015) to reach $9.7 \mathrm{bn}$ US\$, while im ports decreased by 10.9 percent to reach 8.3 bn US $\$$. Exports of this commodity accounted for 0.5 percent of world exports of SITC section 6, and 0.1 percent of total world merchandise exports. China, Italy and Germany were the top exporters in 2015. They accounted for 29.9, 19.2 and 4.8 percent

\footnotetext{
${ }^{2}$ MDG regional groupings are based on UN geographical divisions, with some modifications necessary to create - to the extent possible - groups of countries for which a meaningful analysis can be carried out. MDG regional groupings: Developed regions; Developing regions: Northern Africa, Sub-Saharan Africa, Latin America and the Caribbean; Caucasus and Central Asia; Eastern Asia; Southern Asia; South-eastern Asia; Western Asia; Oceania[1].
} 
of world exports, respectively. China, USA and Germany were the top destinations, with 9.3, 7.7 and 6.0 percent of world imports, respectively.

The top 15 countries/areas accounted for 86.5 and 62.7 percent of total world exports and imports, respectively. In 2015, China was the country/area with the highest value of net exports (+2.1 bn US\$), followed by Italy (+1.4 bn US\$). By MDG regions, the largest surpluses in this product group were recorded by Eastern Asia (+2.1 bn US\$) and Developed Europe ( +1.5 bn US\$). The largest trade deficits were recorded by Developed North America (-448.3 min US\$), South-eastern Asia (-426.4 mil US\$) and South-eastern Europe (-333.3 mil US\$) [2, p.298].

\section{Knitted or Crocheted Fabrics ness, SITC 655}

In 2015, the value (in current US\$) of exports of "knitted or crocheted fabrics", ness (SITC group 655) decreased by 2.6 percent (compared to 1.9 percent average growth rate in 2011-2015 to reach 33.2 bn US\$), while imports decreased by 3.4 percent to reach 26.2 bn US\$. Exports of this commodity accounted for 1.6 percent of world exports of SITC section 6, and 0.2 percent of total world merchandise exports. China, Rep. of Korea and Other Asia ness were the top exporters in 2015. They accounted for 44.1, 10.6 and 8.5 percent of world exports, respectively. Viet Nam, China - Hong Kong SAR and Cambodia were the top destinations, with 13.4, 8.1 and 7.6 percent of world imports, respectively.

The top 15 countries/areas accounted for 91.0 and 66.3 percent of total world exports and imports, respectively. In 2015, China was the country/area with the highest value of net exports (+12.8 bn US\$), followed by Rep. of Korea (+3.4 bn US\$). By MDG regions. the largest surpluses in this product group were recorded by Eastern Asia ( +19.1 bn US\$), Developed Europe (+607.3 mil US\$) and Developed Asia-Pacific (+353.4 min US\$). The largest trade deficits were recorded by South-eastern Asia (-6.7 bn US\$), Southern Asia (-2.3 bn US\$) and Latin America and the Caribbean (-2.1 bn US\$) [2, p. 299].

\section{Position of Poland and the Region of Lodz}

According to the results of the International Ranking, Poland is currently placed 39th in the world with respect to competitiveness, according to the indicators [3, p. 13]. In the European Innovation Scoreboard 2017 Poland is placed on the $25^{\text {th }}$ position among 28 EU Member States [4]. A change in this situation requires growth of innovativeness, as a basic factor of the improvement of competitiveness. It can be achieved only by increasing funding for R\&D (research and development) and for the commercialization of technologies developed.

Throughout the last 15 years, global trends in the trade of textiles and clothing products have been clearly growing, which proves the growing demand for these goods in various regions of the world [5].

In an updated Review of the European Commission concerning the importance of European industry in the changing world, a diagnosis of the situation in 32 sectors of European industry and service sectors is presented. The fashion and design industries provide, admittedly, about $8 \%$ of the European added value in industrial processing, but they are still characterized by a relatively low pace of economic growth. Among the sectors of industry mentioned, in the diagnosis of the state and external com petitive position of the sectors examined with respect to partners and competitors from the Non-EU countries, the importance of Poland was recorded, inter alia, in the sector of the production of textiles and clothing, in which Poland occupies a considerable and growing position in Europe, next to Bulgaria, Greece, Austria and Italy, while the position of France, UK and Ireland is diminishing [5].

In the context of predictions resulting from research performed within the National Foresight Program-Poland 2020, it should be emphasized that the textile industry, based on innovative material technologies, belongs to the main developmental engines of the Polish economy. In the research performed with the Delphi method within the Project Foresight 'Modern technologies for the textile industry. A chance for Poland' it was assumed that the basic criteria for evaluation of hypotheses concerning the technologies examined would be the chance for obtaining a significant competitive position on the international market in the near or distant future. It is, therefore, justified to invest in those technologies that can become competitive not only in the national market but mainly in the international market in the age of the globalization of the economy and significant lowering of customs 
and external-customs barriers in international trade, and especially with their complete abolition on the European market for member countries of the EU [6].

\section{Challenges in the Textile Industry -regional aspects}

In the textile-clothing industry, we have observed in recent times deep technological changes that have revolutionized its outlook. This industry is gradually becoming a world leader in utilizing technologies, technical-technological, product and organizational innovations, especially in the area of technical fabrics, thanks to which it is entering areas that have been so far reserved for high-technology industries. These changes are also taken into consideration in the strategies for the development of light industry, showing crucial areas for the competitiveness of companies, but also showing problems that remain to be solved in them.

The goal of the aforementioned Foresight project was, inter alia, the rational planning of actions aimed at solving those problems in Poland. This article presents the results of research of one of the stages of that project, namely theDelphi Rounds. The method of Delphi Rounds enables to create longterm visions of the future and constitutes a form of long-distance group discussion. It is based on asking selected experts about their opinions on a given topic several times. In the project described two Delphi Rounds were performed, which enabled to organize the data selected and to process the opinions of the experts according to the designated aim of the research [7].

The Region of Lodz is situated in the centre of Poland and characterised by a long and strong industrial traditions. The region stands out for a high level of urbanisation and its main economic centre is Lodz, which is the third largest city in Poland with 696,5 thousands inhabitants.

The Regional Innovation Scoreboard [8] covers 220 regions in 22 EU Member States, Norway, Serbia and Switzerland at different NUTS levels. Most of the Innovation Leaders and Strong Innovators are located in the former EU15 countries in North-West Europe. Most of the Moderate Innovators and Modest Innovators are located in newer Member States and former EU15 countries in the South of Europe. The group of Moderate Innovators includes 85 regions with performance between $50 \%$ and $90 \%$ of the EU average.

According to the Regional Scorebord 2017 the Region of Lodz is ranked as a moderate innovator. It changed recently, previously the region was ranked as modest innovator [8].

\begin{tabular}{|c|c|c|c|c|c|c|}
\hline & & RS2009 & RS 2011 & RS 2013 & RS2016 & RS 2017 \\
\hline PL11 & $\begin{array}{c}\text { Region of } \\
\text { Lodz }\end{array}$ & 46,0 & 47,0 & 47,3 & 50,9 & 51,7 \\
\hline
\end{tabular}

Tab. 1. EU Regional Innovation Scoreboard 2017-Relative Performance to 2009

"There is a strong and positive link between regional innovation performance and regional competitiveness" (Regional Innovation Scorebord 2017)

In this context the most important policy efforts were in the recent time concentrated on the updating of the existing regional innovation strategy (LORIS2030) with the emphasis placed on the smart specialisation issue and development of monitoring instruments with the aim to reinforce targeted innovation policy interventions. The process was finished in May 2013, when the Strategy was officially adopted. The identified areas of smart specialisations of the Region of Lodz include the following sectors of economic activity:

1. Modern textile and fashion industry;

2. Advanced building materials;

3. Medicine, pharmacy, and cosmetic industry;

4. Power generation (including Renewable Energy Sources);

5. Innovative agriculture and agricultural and food processing;

6. Computer science and telecommunication.

This strategy was divided into three priorities, where the first one is dedicated to development of the areas defined as the smart specialisations. In this context, it has to be highlighted that such areas of 
the smart specialisations as modern textile industry, building materials, cosmetics and agricultural and food processing are strongly focused on manufacturing activities. Consequently, development of the activities planned in the Strategy can be seen as the inclusion of the advanced manufacturing approach in the practices of the Region of Lodz. These activities include:

- Launching the 'programmes of exchanges of personnel from the sectors of science and business';

- Implementation of research and development projects in the field of regional specialisations.

Textile and clothing industry geared towards the production of high quality and unique clothing, overcoats and outer garments, cotton, wool and synthetic fabrics, hosiery, towels, velvet, and underwear. This traditional industry has recently seized yet another opportunity to develop and match the international competition.

This has happened largely due to its existing potential, including:

- high-tech textile sector (Pro Humano-Tex)

- highly qualified staff with ample experience and professional expertise

- strong scientific and academic base, including the following universities, institutes and research centres: The Technical University of Lodz - The Faculty of Textile Engineering and Marketing, well known in Europe for its achievements in the field of academic research; University of Lodz; The Academy of Fine Art; The Textile Research Institute; The Institute of Biopolymers and Chemical Fibres; The MORATEX Institute of Security Technologies; The Textile Machine Research and Development Centre at the Institute of Machine Design and Operation; The Central Institute for Labour Protection in Lodz; The Institute of Dyes and Organic Products in Zgierz; The Leather Industry Institute; The Cluster for the Advanced Technologies in the Textile and Clothing Industry, which houses the Polish Technological Platform for Textile Industry.

\section{Circular Economy approach as the solution for the Textile Industry sector in the Future?}

The Circular Economy is an approach that would transform the function of resources in the economy. Waste from factories would become a valuable input to another process - and products could be repaired, reused or upgraded instead of thrown away. Therefore it is why we all should be responsible and innovative from the beginning to the end / from the producer to the user and user to the producer.

The contemporary economic model based on continuous growth may lead to the exhaustion of resources available at acceptable prices and destroy the biological foundations of life to an extent that the mankind will fight over drinking water and food and will suffer from unpredictable, rapid climate changes. Many communities, enterprises and local governments have launched actions designed to limit the consequences of such developments, which pose a threat to life and health on the Earth. The time has come to: seek products and services which are, beginning in the design stage, intended for the longest possible life-cycle; to engage in transformations and the recycling of natural resources; and to exclude toxic materials and processes generating harmful emissions.

This entails striving to build a circular economy founded on: the consumption of resources reduced to the necessary minimum; the use of renewable resources in a way that ensures their regeneration; ecodesign and clean production; consumption of renewable energy; instituting consumption patterns that respect the environment; using wastes as raw materials and processing them without negative external effects. All this means deep systemic changes - not only technological, organizational and social innovation, but changes in financing and new policy instruments.

The idea of a circular economy, which can also be called a 'closed-loop economy', i.e. one that produces minimum waste and in which wastes, if they are generated, become raw materials. The amount of real waste is constantly shrinking. Wastes on our planet can be minimized by the implementation of responsible research to further the innovation principle, i.e., "reduce, reuse, and recycle". This means that each individual must reduce waste and, if he or she has have generated any, reuse it or recycle it.

The circular economy is thus an economy in which production and consumption are organized in such a way that the value of products, components, materials, and resources is maintained within the 
value chain and products' life-cycles. Resource efficiency is maximized while the extraction of raw materials and production of wastes are minimized.

The primary issue is that if we do indeed want to rise to the challenge of an enormous growth of scientific research and innovation than the relationship between science and society has to be interactive. This will not be possible if the public sector - local, regional and national authorities won't be able to give a concrete support - to develop policies or to establish a friendly ecosystem to support this challenge-driven concept. Simultaneously RRI relates to and has an impact on business. The crucial question is IF and HOW governance should respond to the RRI challenges to impose its implementation and to build trust between not only Triple but Quarter Helix Actors: StakeholdersAcademia (research and education communities)-Industry and Business-Government (policy makers) at different levels (national, regional and local).

One of the most useful and effective methodological frameworks to accelerate the transition from the traditional economy to the Circular economy seems to be MISC (Mapping Innovations on the Sustainability Curve), presented by Dr. Anne Snick [9].

Her proposal of "MISC" is not limited to the 'social symptoms' of the present crisis, but addresses its 'social causes', viz. socioeconomic practices as social constructions that are the root cause of both social (inequality, poverty, migration...) and ecological (depletion, pollution, climate change...) crises. The economic transition is a 'social' one in the sense that it rests upon the development of a new paradigm and of new systems to 'allocate scarce resources to the needs of all people - including future generations - while sustaining the ecological conditions of life. "The MISC-methodology concerns the economy in general as a 'social construction' that needs redefining with a view to avoiding both social (exclusion, poverty) and ecological (pollution, depletion) damage. 'Social economy' here refers to economics that is (again) recognized as a human, ethical enterprise that serves needs of all people, including their need for a healthy environment [9].

In the Report presented by the European Commission to the European Parliament the Circular Economy is presented from a product perspective, applying a systemic approach and transition theory [10]. Drivers of product design and usage are discussed in the context of emerging consumption trends and business models. For governance to be effective, it has to address the product life-cycle and the societal context determining it. Indicators and assessment tools are proposed that can help fill the current data and knowledge gaps [10; 11]

We can observe the gap in the implementation of the idea of the Circular Economy between the theory and practice in Western European Universities and Universities in Poland in the context of the EU requirements.

Two main national documents have been developed in Poland which set out the current development directions of the country in the field of sustainable development and environmental protection:

1. Strategy for Responsible Development until the year 2020 (with the perspective until the year 2030)

2. National Waste Management Plan elaborated in the year 2014

The Strategy for Responsible Development sets out one of the directions of Poland's development for the coming years, that is actions contributing to the sustainable development of the country, based on the individual endogenous potential of individual territories as well as actions promoting Polish green technology sector and supporting foreign expansion of Polish entrepreneurs in this sector with the use of new forms of climate finance (Green Climate Fund and Adaptation Fund).

The National Waste Management Plan covers the whole scope of tasks required to provide integrated waste management nationally in a manner securing protection of the environment, with regard to both the present and future economic opportunities and circumstances and technology level of existing infrastructure. The Plan considers tendencies in the present economy worldwide as well as the national circum stances of economic development and includes both the waste prevention scheme in relation to specific types of waste and the strategy for reduction of biodegradable waste landfilling. The Waste Management Plan covers waste originated domestically, including in particular municipal 
waste, hazardous waste, packaging waste and sludges from urban waste water treatment plants, and also waste imported in the national territory. The objectives and tasks presented in the Plan concern years 2011-2014 and the 2015-2022 outlook thereof [12]. The possibility to repair or recycle a product and reuse its components and materials depends largely on the initial design of the product. Following political discussions on eco-design in April and October 2016, the Commission confirmed the importance of smart product design and decided to focus efforts on the product groups with the highest potential in terms of energy and resource savings and further reinforce the evidence base for regulatory action. This resulted in the adoption on 30 November 2016 of the Eco-design Working Plan 2016-2019 as part of the Clean Energy for All Europeans package [13].

In the Region of Lodz during the period from 2016 until 2018 the amount of 5,580 billion PLN from the Structural Funds of the EU was spend for waste management, environmental protection and low emission economy. Funds may be used, among others, for thermo-modernization of buildings, renewable energy sources, waste management. From this point of view the Region of Lodz took the $4^{\text {th }}$ position in Poland [14].

\section{Circular Economy in the Textile Industry - reducing textile waste}

The EU textile industry generates waste estimated at 16 million tons per year. Much of this waste is thrown in landfills or incinerated, with a high environmental impact and at great cost. Valuable resources held within the waste are also lost [15]. One of the most innovative pilot projects, which aims to change this situation in textile industry by focusing on a textile recyding plant is RESYNTEX - which recycles 500 tons of waste per year. This Project strives to implement a circular redesign in the textiles sector. RESYNTEX will transform textile waste into secondary raw materials, creating circularity and reducing environmental impact. Within RESYNTEX the authors have conducted stakeholder consultations in four geographically distinct regions throughout Europe, which utilize different approaches to the collection of textile waste, sourced from consumers, industry and institutions. The project also aims to extract resources and chemicals from the textile waste and recycle them. It proposes innovative technologies covering the whole textile value chain, where the sorted textile waste is chemically treated to extract resources such as protein-based fibres to be used for producing wood panel adhesives; and cellulosic fibres for the production of bioethanol. Polyamide (PA) and polyester (PET) recovery is also carried out to produce new chemicals and plastic bottles [16].

Barriers to circular economy textile solutions are presented in the form of outdated waste legislation and under-provision of commercially viable recycling technologies for low-grade textiles. Collectors are keen to focus solely on 're-wearable' textiles for reuse, neglecting streams for more costly recovery solutions. Continuous management of the transitional economic risks will therefore be imperative for textile collectors to support the circular economy, ranging from certified standards, support for R\&D, access to finance, collaborative innovation mechanisms as well as guarantees on resource supply and price stability. Key drivers for promoting a wider range of recovery streams include policy incentives (such as Extended Producer Responsibility) and economic and environmental strategies such as the diversion of textiles from landfill and Energy from Waste (EfW). Through stakeholder engagement, the researchers within RESYNTEX aimed to propose how conditions for collectors' adoption of circular practices can be improved, while avoiding sectoral disruption and ensuring maximum effectiveness of the redesigned chain of secondary textiles [17].

\section{Germany as the leading country on the list of World's Top Recyclers}

According to the Organization for Economic Cooperation and Development, Germans happily sort 65 percent of their waste into an array of color-coded bins to be collected for reuse or incineration. South Koreans come in second, recycling 59 percent of their refuse. The United States recycles 35 percent; that's only slightly above the average for the developed countries that belong to the OECD but it is miles ahead of Turkey, where 99 percent of all trash ends up in a landfill [18]. Landfill remains the major disposal method for municipal waste. A person living in the OECD area generates on average $520 \mathrm{~kg}$ of waste per year; this is $30 \mathrm{~kg}$ less than in 2000, though still $20 \mathrm{~kg}$ more than in 1990 (see results presented in two figures below). 


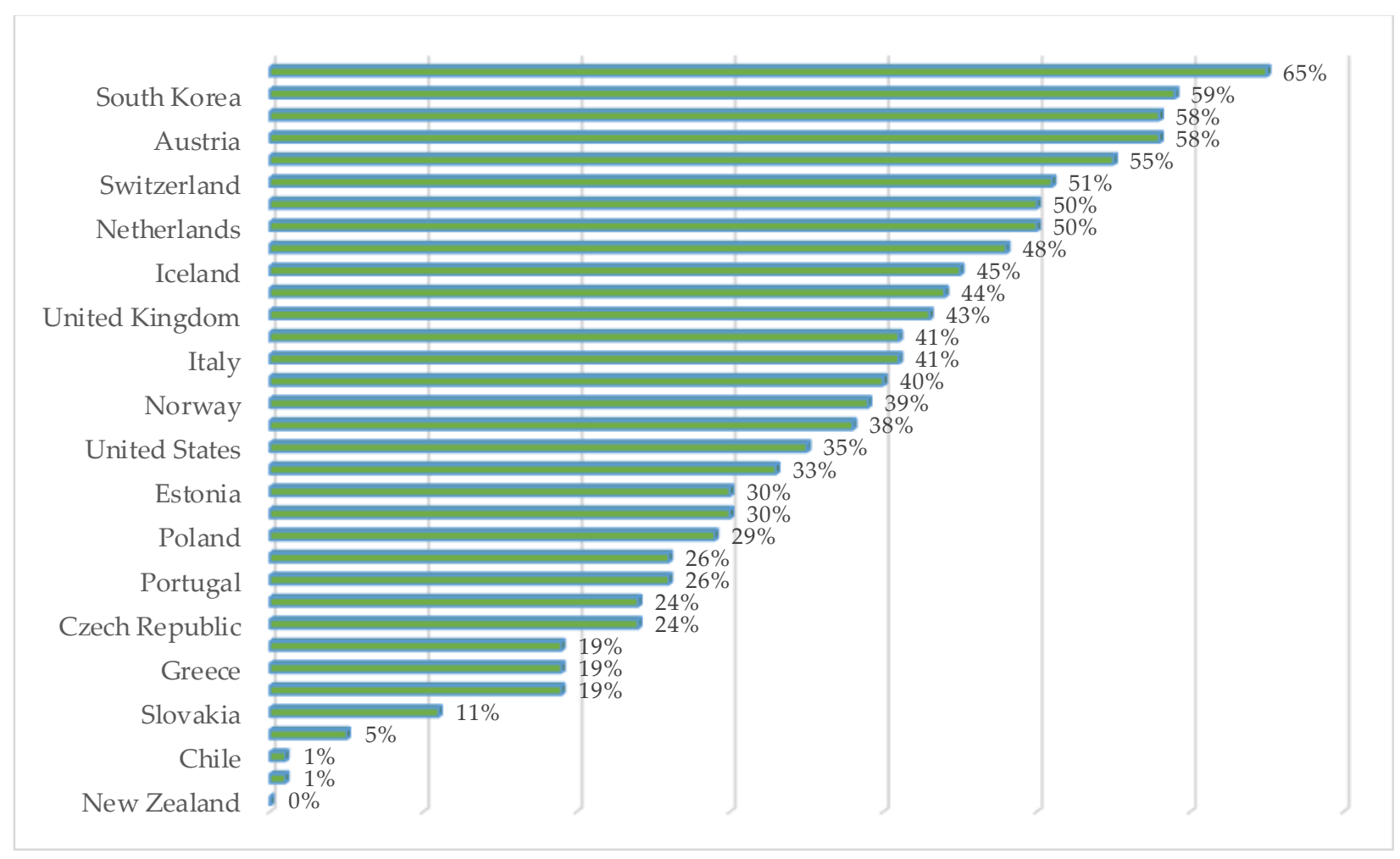

Fig. 1. Name Countries winning the recycling race. Recycled and composted waste as a share of total municipal waste in OECD countries (2013) [19]

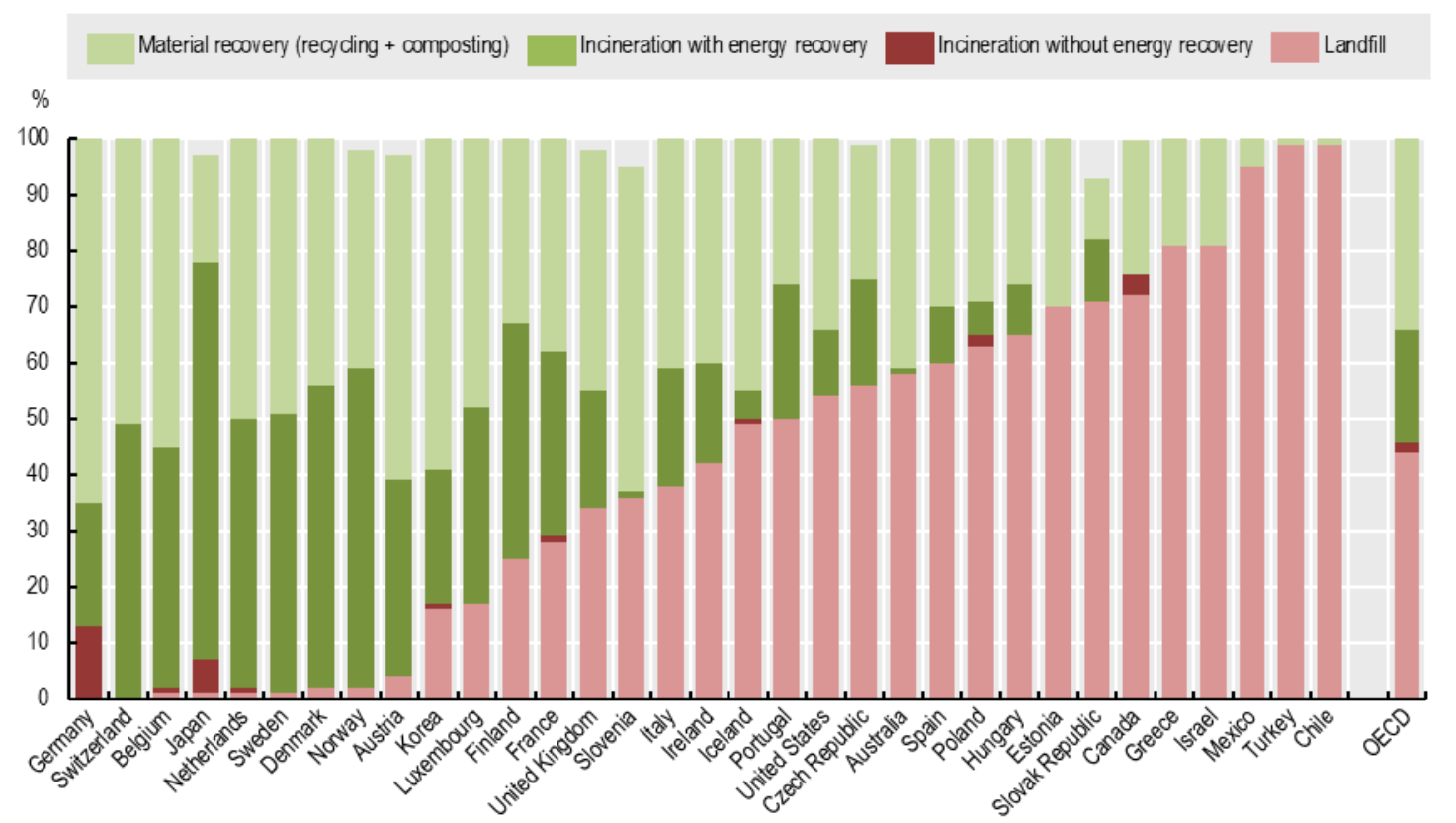

Fig. 2. Municipal waste disposal an recovery: recycling, incineration, landfilling [20]

\section{CONCLUSIONS}

Textile industry belonging to rapidly developing sectors of the global economy is gradually changing its current character. On the one hand, the demand for textiles, knitwear and textiles continues to grow as the world population increases. On the other hand, there is also a gradual increase in awareness that this is an industry generating a huge amount of waste, especially when production is not based on sustainable production and consumption patterns and when it is massive and to a small extent takes into account the needs of individual customers. 
This approach causes growing problems related to environmental pollution and contributes to the increase of adverse climate change im pacts.

Striving for the development of sustainable production and consumption in accordance with the circular economy trends creates a framework for switching production to its innovative types, which will be based on:

- generation of minimal waste in the production process $(1 \mathrm{R}$ - with application of the most innovative technology),

- its maximum re-use (2R),

- application of the third method within the three $\mathrm{R}$ formula (reduce, reuse, recycle) which is recycling (3R), the awareness of the importance of which among producers and citizens in many countries is systematically growing - as presented on Fig. 1.

The new approach obviously requires adjusting production not only to new ecological and quality standards, but making an efforts to awaken the international community's need for greater care for the natural environment, especially by countries taking distant positions in world recycling development rankings. It also requires greater solidarity of countries on a global scale.

\section{REFERENCES}

[1] A new textiles economy: Redesigning fashion's future. Available at: https://www.ellenmacarthurfoundation.org/assets/downloads/publications/A-New-Textiles-Economy_ Summary-of-Findings_Updated_1-12-17.pdf

[2] International Trade Statistics Yearbook. Vol. II. United Nations, Geneva, 2016/17.

[3] Schwab K. (Ed.) The Global Competitiveness Report 20172018. World Economic Forum, Geneva, 2017. Available at: http://www3.weforum.org/docs/GCR2017-2018/05FullReport/TheGlobalCompetitiveness Report2017\%E2\%80\%932018.pdf

[4] The European Innovation Scoreboard 2017. Available at: https:/www.rvo.nl/sites/default/ files/2017/06/European_Innovation_Scoreboard_2017.pdf

[5] According to Comtrade data-base UN.

[6] Wysokińska Z. Rundy Delfickie. Scenariusze. Założenia dla Polityki innowacyjnej w obszarze technologie włókiennictwa. In: Ciechańska D. (Ed.) Foresight. Nowoczesne Technologie dla Włókiennictwa. Szanse dla Polski. Instytut Biopolimerów i Włókien Chemicznych, Lodz, 2014. (in Polish)

[7] Wysokińska Z., Koszewska M., Czajkowski T, Malinowska-Olszowy M. Future of the Polish Textile Industrial Sector. An Overall Analysis of the Empirical Research Performed with the Delphi Method within the Project Foresight 'Modern Technologies for the Textile Industry. A Chance for Poland'. Fibres $\mathcal{E}$ Textiles in Eastern Europe, 201321 (4(100)), 10-15. Available at: http://www.fibtex.lodz.pl/article945.html

[8] Regional Innovation Scoreboard. Available at: https://www.ewivlaanderen.be/sites/default/files/imce /ris2017_executive_summmary_en.pdf

[9] Dr. Snick A. MISC: Mapping Innovations on the Sustainability Curve. A methodological framework to accelerate the transition. Available at: http://cesie.org/media/MISC-methodological-framework.pdf

[10] Circular by Design. European Environmental Agency. EEA Report No 6/2017. Available at: https://www.eea.europa.eu/publications/circular-by-design

[11] European Commission. Report from the Commission to the European Parliament, The Council, the European Economic and Social Committee and the Committee of Regions. Brussels, 26.1.2017, COM(2017) 33 final. Available at: http://ec.europa.eu/environment/circular-economy/implementation_report.pdf

[12] The National Waste Management Plan 2014 in Poland. Available at: https://climateobserver.org/wpcontent/uploads/2014/09/Poland_National-Waste-Management-Plan-2014.pdf

[13] European Commission. Communication from the Commission. Brussels, 30.11.2016, COM(2016) 773 final. Available at: https://ec.europa.eu/energy/sites/ener/files/documents/com_2016_773.en_.pdf 
[14] Available at: https://www.pb.pl/lodzkie-rpo-rozdysponuje-blisko-22-mld-zl-851972

[15] Available at: https://ec.europa.eu/easme/en/news/circular-economy-practice-reducing-textile-waste

[16] RESYNTEX received funding from the European Union's Horizon 2020 research and innovation program under grant agreement 641942. Available at: http://resyntex.eu

[17] Boiten V.J., Han S., Tyler D. Textile collection strategies to support material circularity. Available at: http://www.resyntex.eu/images/downloads/ValrieJBoiten_Textile_collection_strategies.pdf

[18] Available at: https://www.nytimes.com/2016/11/28/world/what-in-the-world/germany-gleefully-leadslist-of-worlds-top-recyclers.html?rref=collection\%2Ftimestopic\%2FWaste\%20Materials $\% 20$ and $\% 20$ Disposal

[19] Available at: https://www.forbes.com/sites/niallmccarthy/2016/03/04/the-countries-winning-therecycling-race-infographic/\#752df3182b3d

[20] Available at: http://www.oecd.org/env/environment-at-a-glance-19964064.htm

Address: Zofia Wysokińska, University of Lodz, 68, Narutovicha Str., Lodz, 90136, Poland.

E-mail: zofwys@gmail.com

Received: 12.06.2019; revised: 22.10.2019.

Високінська Зофія. Інновації текстильної промисловості та іï перспективи в концепції кругової економіки - від глобальної до регіональної перспективи. Журнал Прикарпатського університету імені Василя Стефаника, 6 (3-4) (2019), 67-76.

У статті проведено комплексний аналіз виробництва, експорту та імпорту продуктів у текстильній промисловості у різних країнах світу. Визначено найбільших виробників та експортерів текстильної продукції. Проаналізовано тенденції зміни виробничих потужностей у даній галузі впродовжостанніх років. Обгрунтовано місце і роль розвитку текстильної промисловості в контексті реалізації принципу Кругової економіки відповідно до пріоритетів ЄС. Визначено основні напрямки перспективного розвитку текстильної галузі в контексті реалізації двох основн их національних документів, що розроблені в Польщі, які визначають поточні напрямки розвитку країни у сфері сталого розвитку та охорони навкодишнього середовища: Стратегія відповідального розвитку до 2020 року (з перспективою до 2030 року) та Національний план управління відходами розроблений у 2014 році. У статті подано детальний аналіз розвитку регіональної промисловості, включаючи текстильну промисловість на базі міста Лодзь (Польща). Визначені сфери розумних спеціалізацій регіону Яодзь, які включають такі галузі економічної діяльності: сучасна текстильна та модна промисловість; сучасні будівельні матеріали; медицина, фармація та косметична промисловість; виробництво енергії (включаючи поновлювані джерела енергіi); інноваційне сільське господарство та переробка сільського господарства та продовольства; інформатика та телекомунікації. У статті запропоновано основні напрямки розвитку текстильної галузі на прикладі Польщі: 1) утворення мінімадьних відходів у виробничому процесі (1R - із застосуванням найбільш інноваційної технологіi), 2) максимальне повторне використання (2R), 3) застосування третього методу в межах трьох формул $\mathrm{R}$ (зменшення, повторне використання, переробка), що переробляе (3R), усвідомлення важливості цього серед виробників та громадян систематично зростає.

Ключові слова: текстильна промисловість, кругова економіка, глобальна економіка, переробка, відходи, виробничий процес. 